\title{
Reis Filho, Daniel Aarão Luís Carlos Prestes: um revolucionário entre dois mundos
}

[Luís Carlos Prestes: a revolutionary between two worlds]

Jean Rodrigues Sales ${ }^{\star}$

\section{Reis Filho, Daniel Aarão}

\section{Luís Carlos Prestes: um revolucionário entre dois mundos}

São Paulo: Companhia das Letras, 2014. 576p.

Luís Carlos Prestes was born in January 1898 and died in March 1990. During his long life he participated in significant moments in Brazilian history, and of the left in particular. In the 1920s, he was one of the leaders of the movement which spread throughout Brazil in opposition to the administration of Artur Bernardes and to way the republication regime was organized. In the 1930s he spent a long period in the Soviet Union, where he definitely adhered to communism and prepared the way to joining the Brazilian Communist Party (Partido Comunista Brasileiro - PCB). After returning to Brazil he participated in the so-called Intentona Comunista (Communist Uprising) in 1935. After the defeat of this he was imprisoned for various years, until he reemerged in the second half of the 1940, leading a reinvigorated PCB after the end of the war.

During the Dutra administration, he faced a new period of persecutions after the revocation of the PCB's official registration, once again having to go underground. From the end of the 1950s until the 1964 coup he, along with the PCB, experienced the intense years of the Juscelino Kubitschek and Jânio Quadros administrations, the resignation of the latter, and the troubled assumption of João Goulart. Between 1961 and 1964, he was present during the debates of the Grassroots Reforms (Reformas de Base) and other development projects for the country. After the coup, he spent a new and long exile in the Soviet Union, from where he accompanied and was a protagonist in the organic crisis of the PCB. Returning to Brazil in 1979, until his death he directly

\footnotetext{
* Programa de Pós-Graduação em História, Universidade Federal Rural do Rio de Janeiro (UFRRJ). Nova Iguaçu, RJ, Brasil. jeanrodrigues5@yahoo.com.br
} 
or indirectly participated in the great events related to re-democratization. In general terms, he adopted a position that was critical of the PCB, the parties of the left and the so-called New Republic.

Due to the dimension of Prestes' participation in the events summarized here, we can ask ourselves here about the feasibility of writing a complete biography about his personal and political trajectory during a life of almost a century. The difficulties raised by a venture of this nature can explain the fact that the book Luís Carlos Prestes: um revolucionário entre dois mundos is the first to assume this task. ${ }^{1}$

In order to take into account the great complexity of the long period studied, Daniel Aarão Reis has divided the trajectory of Prestes into three large periods, demarcated by broader political events and by Prestes' history within the PCB: 1898-1935; 1936-1964, and 1964-1990.

In addition to the merit of writing a biography of a representative figure from the Brazilian left in the twentieth century, the strongest point in the book is the use of a wide range of sources: interviews with activists and former activist who knew Prestes, both those who remained close to or admirers of the legacy of the communist leader, and the critics and those who historically disaffected, allowing an analysis of the trajectory of his biography within the party machine; interviews with family members, allowing a glimpse of the personal aspects of this trajectory; sources from the Soviet regime and the Communist International researched in Moscow, and finally, but very relevant, audio recordings of meetings of the Central Committee of the PCB made in exile. Access to the recordings, until then unheard, allowed the analysis of the perceptions of PCB leaders in relation to the situation of the party in the scenario before the return from exile in 1979, and Prestes' own position at that moment. The debates held by the Central Committee abroad, which appear in the recordings, also help to understand Prestes' withdrawal from the PCB during the 1980s.

In a book of this nature, it will always be possible to point to the lack of certain themes, the need for greater depth in this or that aspect of Prestes' trajectory, as well as implicit approaches in the history of Brazil or of communism. These are the cases, for example, of the relations of the PCB and of Prestes himself with workers during the twentieth century. Similarly, it is possible to disagree with an interpretation which permeates the book, suggesting that Luís Carlos Prestes' options had been spent on an impossible dream: a socialist revolution in Brazil. It would perhaps have been useful to expand the analysis and note that during the twentieth century revolutions occurred in 
countries in which they were not expected, as well as the victory of the struggles of various peoples in the Third World from the Post-War period onwards.

There are also those who have pointed to factual mistakes in the narrative, but these, in my opinion, do not cause important harm to the text, although they involve important questions about Prestes' personal life. However, the author and publishers' choice of a form of citation in which at certain moments the sources used as support for the analyses of the book cannot be completely found, has generated discomfort, principally among historians. ${ }^{2}$ While, on the one hand, the editorial decision has the positive aspect of allowing a fluid narrative, necessary in a book of more than five hundred pages, on the other hand, the imprecision of citations can be noted. This characteristic of the work, which would be controversial in any history book, looms large by dealing with a question which is in itself controversial, such as the life and legacy of Luís Carlos Prestes, making criticisms and divergences almost inevitable.

As can be seen, the book has superlative and complex aspects, which portray Prestes' life. The divergences about its result denote the complexity of the task. As a result, whether agreeing or disagreeing with the analyzes of Daniel Aarão Reis, it is essential reading for those who want to know the history of Prestes and communism in the twentieth century.

\section{NOTES}

${ }^{1}$ The researcher and daughter of Luís Carlos Prestes, Anita Leocádia Prestes, published various works about aspects of the trajectory of her father, but these did not exactly constitute a biography.

${ }^{2}$ For some of these criticisms see: PRESTES, Anita Leocádia. "Daniel Aarão Reis e a biografia de Luiz Carlos Prestes: a falsificação da história por um historiador". In: www. ilcp.org.br/prestes/index.php?option $=$ com_content $\& v i e w=$ article\&id $=325$ :daniel-aaraoreis-e-a-biografia-de-luiz-carlos-prestes-a-falsificacao-da-historia-por-um-historiador\&catid=18:artigos\&Itemid=140; Acesso em: 12 abr. 2015.

Review received on April 13, 2015. Approved on April 13, 2015. 